\title{
Application of chitosan on physalis
}

\author{
Aplicação de quitosana em physalis \\ Aplicación de quitosano en physalis
}

\begin{abstract}
Cultivation of small fruits such as blackberry, raspberry, blueberry, strawberry, and physalis is rapidly growing in Brazil, mainly due to small producers who seek income diversification. The aim of this study was to evaluate the effect of foliar application of different doses of chitosan on the physicochemical properties of Physalis peruviana L. Two experiments were conducted: i) field (FE); and ii) greenhouse (GE). Four doses of chitosan $\left(0.1,0.2,0.3\right.$, and $\left.0.4 \mathrm{~L}^{100 \mathrm{~L}^{-1}}\right)$ and a control were used as treatments. We evaluated fruit diameter (FD), fruit length (FL), calyx length (CL), and calyx diameter (CD) - mm; fruit mass - g; soluble solids content (SS) - ${ }^{\circ}$ Brix; titratable acidity (TA) - \% of citric acid; SS/TA ratio; and fruit firmness - N. Foliar application of chitosan to field-grown physalis plants significantly increased fruit mass, length, and diameter, as well as fruit SS and TA content. However, in a protected environment, the application of chitosan had less effect on the properties evaluated. Fruit firmness was not affected by chitosan application. Negative correlations $(\mathrm{P}<0.001)$ between fruit mass and firmness $(\mathrm{r}=-0.57)$ and SS/TA ratio $(\mathrm{r}=-0.61)$ were observed. SS/TA ratio was also negatively correlated with TA $(\mathrm{r}=-0.82), \mathrm{FL}(\mathrm{r}=-0.61)$, and FD $(\mathrm{r}=-0.68)$. High and significant correlations were observed between fruit mass and TA, FL, and FD. Foliar application of chitosan has a positive effect on both agronomic and chemical properties and can be an excellent alternative natural fertilizer for physalis plants when applied in doses

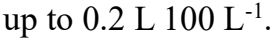

Keywords: Crustacean exoskeleton; Resistance inducer; Physalis peruviana L.; Solanaceae.

\section{Resumo}

No Brasil o cultivo de pequenos frutos como amora-preta, framboesa, mirtilo, morango e fisális encontra-se em plena expansão, principalmente por pequenos produtores, que buscam a diversificação da renda. O objetivo deste trabalho foi avaliar os aspectos físico-químicos do fruto de Physalis peruviana L. submetido a aplicação foliar de diferentes doses 
de quitosana. Foram realizados dois ensaios: i) campo (CP), com 8 repetições; e ii) casa de vegetação (CV), com 5

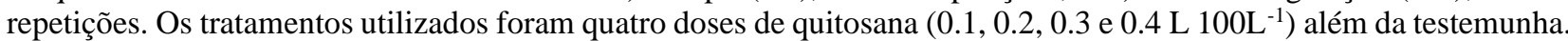
Foram avaliados o diâmetro (DF) e comprimento do fruto (CF) e capulho (CC) em mm, a massa dos frutos (g), o teor de sólidos solúveis (SS) - ${ }^{\circ}$ Brix, Acidez titulável (AT) - \% de ác. cítrico, a relação (SS/AT) e a firmeza dos frutos - N. A aplicação foliar de quitosana em plantas de fisalis a campo aumentou significativamente a massa, o comprimento e diâmetro dos frutos, além do teor de SS e AT dos frutos. Entretanto, quando aplicado em ambiente protegido houve menor efeito da quitosana sobre as variáveis avaliadas. A firmeza dos frutos não foi influenciada pela aplicação de quitosana. Verificou-se correlações negativas $(\mathrm{P}<0.001)$ entre a massa dos frutos e a firmeza $(\mathrm{r}=-0.57)$ e a relação SS/AT $(\mathrm{r}=-0.61)$. A relação SS/AT também está negativamente correlacionada com AT ( $\mathrm{r}=-0.82), \mathrm{CF}(\mathrm{r}=-0.61)$ e $\mathrm{DF}(\mathrm{r}=-0.68)$. Correlações altas e significativas foram encontradas envolvendo a massa dos frutos e AT, CF e DF. Os resultados demonstram que a aplicação de quitosana foliar tem efeito positivo tanto para variáveis agronômicas quanto químicas e pode ser uma excelente alternativa de fertilizante natural para a cultura da fisalis quando aplicado em doses de até 0.2 L $100 \mathrm{~L}^{-1}$ de água.

Palavras-chave: Exoesqueleto de crustáceos; Indutor de resistência; Physalis peruviana L.; Solanaceae.

\section{Resumen}

En Brasil, el cultivo de pequeños frutos como mora, frambuesa, arándano, fresa y physalis está en plena expansión, principalmente por pequeños productores, que buscan diversificar sus ingresos. El objetivo de este trabajo fue evaluar los aspectos fisicoquímicos del fruto de Physalis peruviana L. sometido a la aplicación foliar de diferentes dosis de quitosano. Se realizaron dos ensayos: i) campo (CP), con 8 repeticiones; y ii) invernadero $(\mathrm{CV})$, con 5 repeticiones. Los

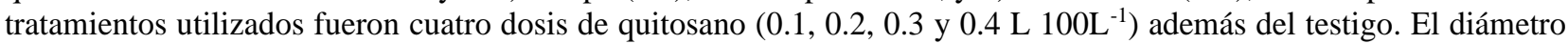
(DF) y longitud del fruto (CF) y cápsula (CC) en mm, la masa del fruto (g), el contenido de sólidos solubles (SS) ${ }^{\circ}$ Brix, Acidez titulable (AT) - \% de B.C. cítricos, la relación (SS/AT) y firmeza del fruto - N. La aplicación foliar de quitosano en plantas de physalis en campo incrementó significativamente la masa, longitud y diámetro de los frutos, además del contenido de SS y AT de los frutos. Sin embargo, cuando se aplicó en un ambiente protegido, hubo un menor efecto del quitosano en las variables evaluadas. La firmeza de la fruta no se vio afectada por la aplicación de quitosano. Se observaron correlaciones negativas $(\mathrm{P}<0.001)$ entre la masa del fruto y la firmeza $(\mathrm{r}=-0.57)$ y la relación SS/TA ( $r=-0.61)$. La relación SS/TA también se correlacionó negativamente con TA $(r=-0,82)$, FL( $r=-0,61)$ y FD ( $r=-$ 0,68). Se observaron correlaciones altas y significativas entre la masa de frutos y TA, FL y FD. La aplicación foliar de quitosano tiene un efecto positivo tanto en las propiedades agronómicas como químicas y puede ser una excelente

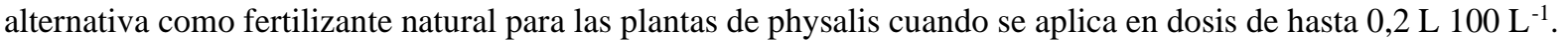

Palabras clave: Exoesqueleto de crustáceo; Inductor de resistencia; Physalis peruviana L.; Solanáceas.

\section{Introduction}

Physalis (Physalis peruviana L.) is cultivated in several regions of the world (Scher et al., 2014) and is easily propagated and dispersed (Njoroge et al., 2004). Its fruits contain phenolic compounds, polyphenols, flavonoids, carotenoids, steroids, physalins, vitamins, and minerals (Puente et al. 2011; Machado et al., 2019; Mier-Giraldo et al., 2017; Marchioretto et al., 2020). These compounds have antioxidant activities that can be beneficial for health (Puente et al., 2011).

In Brazil, physalis is cultivated mainly for income diversification in small rural properties, since it has low implementation cost, production capacity in a short period of time, possibility of organic cultivation and commercialization in natura, besides being in short supply (Muniz et al., 2011; Rodrigues et al., 2014).

Because of consumers' demand, growing physalis with agroecological practices can facilitate its commercialization. In this context, using products such as chitosan, a natural heteropolymer, can be an alternative to aid fruit development (Kurtz et al., 2010, Amerany et al. 2020). Chitosan is extracted from crustaceans' exoskeleton and the cell wall of some fungi of the Zygomycete class (Kumar, 2000).

Chitosan properties allow numerous applications in various commercial products, due to its biocompatibility, biodegradability, and amine reactivity (Fai et al., 2011; Synowiecki and Al-Khatteb, 2003). Among other applications, chitosan has been used as a bioprotectant that improves plant and fruit development (Sathiyabama et al., 2016; Trouvelot et al., 2014; Amerany et al., 2020; Sathiyabama and Akila, 2021). Chitosan induces defense mechanisms such as increased production of phytoalexins, which are only produced on a large scale when the plant is subjected to a pathogen attack. Application of chitosan 
can also increase the concentration of salicylic acid and other phenolic compounds, acting as an efficient plant defense inducer (Berger et al., 2011).

Despite the low cost of establishing a physalis plantation, paying attention to management and phytosanitary treatments is crucial (Muniz et al., 2014; Valdivia-Mares et al., 2016). The use of chitosan in adequate amounts can be an alternative for farmers to achieve sustainable physalis cultivation. Studies using chitosan in physalis cultivation are scarce. Therefore, the aim of this study was to evaluate the effect of different doses of chitosan on the physicochemical properties of Physalis peruviana L.

\section{Material and Methods}

The present study was carried out under two conditions: i) in the field; and ii) in a greenhouse. It was not the objective of this study to compare the two production environments.

\subsection{Experiment I: field}

The first experiment was conducted in the experimental area of the Federal University of Paraná, Setor Palotina, Paraná, Brazil. The soil of this region is classified as Eutroferric Red Latosol with clayey texture (Embrapa, 2018). The region's climate, according to Köppen's classification, is Cfa - humid subtropical, with hot summers and cold or mild winters, average annual rainfall of $1,508 \mathrm{~mm}$, average temperature of $20.8{ }^{\circ} \mathrm{C}$, and no defined dry season (Caviglione et al., 2000).

The experiment followed a randomized blocks design, with eight blocks. Each experimental unit consisted of a single

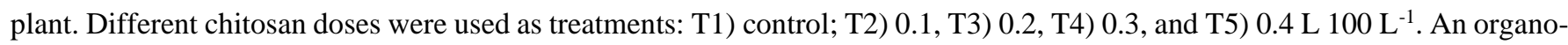
mineral fertilizer based on fermented fish (Fert-I-Fish - Agrobiologica) was used as a source of chitosan. Treatments were sprayed on the plants weekly from 30 days after transplanting until the end of the experiment (approximately 7 weeks).

Soil analysis (Table 1) was performed before transplantation. Fertilization was performed as recommended by Trani et al. (2015) for tomato crops since they are also a solanaceous plant and there is no recommendation for physalis cultivation in Brazil. Pest and weed control was carried out periodically and whenever necessary.

Table 1. Chemical analysis of the field soil.

\begin{tabular}{|c|c|c|c|c|c|c|c|c|c|c|}
\hline \multirow{2}{*}{ Depth $(\mathrm{cm})$} & \multirow{2}{*}{$\begin{array}{c}\mathrm{OM} \\
\left(\mathrm{g} \mathrm{dm}^{-3}\right)\end{array}$} & \multirow{2}{*}{$\begin{array}{c}\mathrm{P} \\
\left(\mathrm{mg} \mathrm{dm}^{-3}\right)\end{array}$} & \multicolumn{6}{|c|}{ Exchangeable cations $\left(\mathrm{cmol}_{\mathrm{c}} \mathrm{dm}^{-3}\right)$} & \multirow{2}{*}{$\begin{array}{l}\text { SB } \\
(\%)\end{array}$} & \multirow{2}{*}{$\begin{array}{c}\mathrm{pH} \\
\left(\mathrm{CaCl}_{2}\right)\end{array}$} \\
\hline & & & $\mathrm{K}^{+}$ & $\mathrm{Mg}^{2+}$ & $\mathrm{Ca}^{2}$ & $\mathrm{Al}^{3+}$ & $\mathrm{H}+\mathrm{Al}$ & CEC & & \\
\hline $0-20$ & 28.71 & 23.85 & 0.86 & 1.65 & 5.16 & 0.00 & 3.34 & 11.01 & 7.67 & 5.24 \\
\hline $20-40$ & 24.61 & 38.88 & 0.37 & 2.06 & 5.41 & 0.00 & 3.62 & 11.46 & 7.84 & 5.21 \\
\hline \multirow{2}{*}{ Depth $(\mathrm{cm})$} & \multicolumn{10}{|c|}{ Micronutrients $\left(\mathrm{mg} \mathrm{dm}^{-3}\right)$} \\
\hline & \multicolumn{3}{|c|}{$\mathrm{Cu}$} & \multicolumn{3}{|c|}{$\mathrm{Zn}$} & \multicolumn{2}{|c|}{$\mathrm{Mn}$} & \multicolumn{2}{|r|}{$\mathrm{Fe}$} \\
\hline $0-20$ & \multicolumn{3}{|c|}{9.90} & \multicolumn{3}{|c|}{5.40} & \multicolumn{2}{|c|}{118} & \multicolumn{2}{|c|}{22.30} \\
\hline $20-40$ & \multicolumn{3}{|c|}{10.60} & \multicolumn{3}{|c|}{5.70} & \multicolumn{2}{|c|}{101} & \multicolumn{2}{|c|}{16.80} \\
\hline
\end{tabular}

Sum of bases (BS), Cation Exchange Capacity (CEC). Source: Authors.

We used a single espalier conduction system, with a spacing of $0.8 \mathrm{~m}$ between plants. Plants were staked using bamboo stakes. Pruning was only performed to improve plant architecture by removing excess branches and leaving productive branches. To meet crop water requirement, a drip tape irrigation system with emitter spacing of $0.3 \mathrm{~m}$ and flow rate of $1.5 \mathrm{~L} \mathrm{~h}^{-1} \mathrm{was}$ installed and used when the soil was slightly dry. Weed control was performed manually. No chemicals were used for pest and disease control. 


\subsection{Experiment II: greenhouse}

The experiment was conducted in a greenhouse of the Universidade Federal do Paraná, Setor Palotina, Paraná, Brazil. The soil used to fill the pots $(12 \mathrm{~L})$ was the same as that of the field experiment, classified as Eutroferric Red Latosol with clayey texture (Embrapa, 2018). Fertilization, cropping system, and pest and disease management were the same as those of the field experiment. Irrigation was carried out by an automated micro-sprinkler with a timer programmed for two daily irrigations. When necessary, irrigation was supplemented with a watering can.

We employed a randomized experimental design, with five repetitions. Each experimental unit consisted of a $12 \mathrm{~L}$ black plastic pot containing a single plant. We used the following doses of chitosan as treatments: T1) control; T2) 0.1, T3) 0.2, T4)

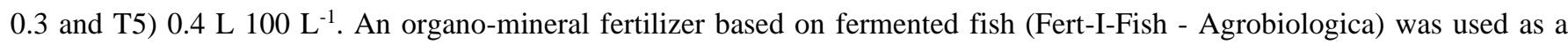
source of chitosan. Treatments were sprayed on plants weekly from 30 days after transplanting until the end of the experiment (approximately 7 weeks).

\subsection{Obtaining seedlings}

Physalis (Physalis peruviana L.) seedlings were obtained from seeds (from a commercial plantation) extracted from ripe fruits using a blender and water. After seeds were separated through a sieve, they were dried in the shade. A single seed was sown per cell in 150-cell polypropylene trays containing commercial Plantmax ${ }^{\circledR}$ substrate and placed in a heated greenhouse for germination. Seeds germinated approximately 20 days after sowing (DAS). 30 days after emergence (DAE), when plants were approximately $0.015 \mathrm{~m}$ tall, they were transplanted to the field.

\subsection{Harvest and evaluation}

Agronomic and chemical properties of the fruits were evaluated during harvest. Fruits were harvested by hand twice a week, when the color of the calyces was greenish-yellow. Harvesting and fruit evaluation were carried out over 7 weeks. The following were evaluated: (i) diameter and length of fruits and calyces (mm), using a digital pachymeter and picking three fruits at random per experimental unit; (ii) fruit biomass $\left(\mathrm{g}\right.$ fruit $\left.{ }^{-1}\right)$, by weighing the total fruits with stalk and calyx using a digital precision scale and dividing by the amount of fruits per plant; (iii) fruit firmness $(\mathrm{N})$, measured in five fruits (in two opposite points) per experimental unit using a penetrometer (GY-2, with 0.02 resolution).

We evaluated the following chemical properties: i) total soluble solids content (SS), ii) titratable acidity (TA), and iii) ratio (SS/TA). SS content was obtained using a bench refractometer that measures the Brix degree ( ${ }^{\circ}$ Brix). TA (\% of citric acid) was determined after crushing 10 fruits per experimental unit using a mixer, filtering and separating $0.005 \mathrm{~L}$ of juice, completing to $0.05 \mathrm{~L}$ with distilled water, adding 2 to 3 drops of $1 \%$ phenolphthalein indicator and titrating with a $0.050 \mathrm{~L}$ graduated burette with $0.1 \mathrm{~N} \mathrm{NaOH}$ solution standardized with potassium biphthalate (Adolfo Lutz Institute, 2008).

\subsection{Statistical analysis}

Data were tabulated and submitted to tests of homogeneity of variance and normal distribution (Kolmogorov Smirnov and Shapiro Wilk). Data were then subjected to analysis of variance (ANOVA). When there was significance, a regression analysis was performed to test the best model to fit the data, as recommended by Ferreira (2008). These analyses were performed using the Sisvar software (Ferreira, 2008). A Pearson correlation analysis ( $r$ ) was performed between all variables using the mean of the variables evaluated in both experiments ( $\mathrm{n}=63$ ) and employing the $\mathrm{R}$ Core Team (2020) package.

A multivariate principal component analysis (PCA) was also performed for each experimental condition using the Past software (Hammer et al., 2001). All data were obtained from the Pearson correlation matrix using broken-stick principal components (PCs) retention criteria. 


\section{Results and Discussion}

Little is known about the efficiency of chitosan as a source of fertilization and protection for physalis plants. We chose to evaluate the effects of different doses of chitosan on physalis plants in two experimental conditions (field and greenhouse) because chitosan is a natural biofertilizer, environmentally sustainable, and has a high potential for use in plants (Sathiyabama and Akila, 2021).

There was a significant effect of chitosan doses for the variables SS, TA, FM, CL, CD, FL, and FD in the field experiment (Table 2). In the greenhouse experiment, doses showed a significant effect only for the variables SS, TA, and FM (Table 2). The coefficients of variations observed were low for all parameters evaluated (Table 2), unlike what was observed by Saavedra et al. (2019) for different populations of $P$. angulata in Mexico.

Table 2. ANOVA of the properties evaluated in the two experimental conditions (Field and Greenhouse).

\begin{tabular}{|c|c|c|c|c|c|c|c|c|c|c|}
\hline $\begin{array}{l}\text { Source } \\
\text { Variation }\end{array}$ & $\mathrm{df}$ & $\begin{array}{l}\text { SS } \\
{ }^{\circ} \text { Brix }\end{array}$ & TA & $\begin{array}{l}\text { Ratio } \\
\text { (SS/TA) }\end{array}$ & $\mathrm{FF}$ & FM & $\mathrm{CL}$ & $\mathrm{CD}$ & FL & FD \\
\hline \multicolumn{11}{|c|}{ Field } \\
\hline Doses & 4 & $\mathrm{P}<0.001$ & $\mathrm{P}<0.05$ & 0.0741 & 0.2340 & $\mathrm{P}<0.05$ & $\mathrm{P}<0.05$ & $\mathrm{P}<0.001$ & $\mathrm{P}<0.001$ & $\mathrm{P}<0.001$ \\
\hline $\mathrm{CV}(\%)$ & & 1.71 & 3.59 & 3.65 & 6.55 & 7.82 & 6.62 & 5.94 & 3.40 & 2.70 \\
\hline Average & & 13.319 & 1.942 & 6.848 & 3.753 & 4.042 & 34.556 & 29.997 & 19.367 & 18.683 \\
\hline \multicolumn{11}{|c|}{ Greenhouse } \\
\hline Doses & 4 & $\mathrm{P}<0.05$ & $\mathrm{P}<0.001$ & 0.1676 & 0.3489 & $\mathrm{P}<0.001$ & 0.0641 & 0.5331 & 0.3075 & 0.2492 \\
\hline $\mathrm{CV}(\%)$ & & 2.57 & 2.57 & 4.43 & 4.14 & 3.16 & 1.65 & 2.07 & 1.86 & 2.34 \\
\hline Average & & 13.120 & 1.796 & 7.318 & 4.268 & 3.156 & 35.734 & 30.279 & 17.152 & 16.606 \\
\hline
\end{tabular}

df: degree of freedom; SS: Soluble Solids; TA: Titratable acidity; FF: Firmness; FM: Fruit mass; CL: Calyx length; CD: Calyx diameter; FL: Fruit length; FD: Fruit diameter. Source: Authors.

Doses showed a quadratic behavior for fruit mass, length and diameter, calyx length and diameter (Figure 1) of the

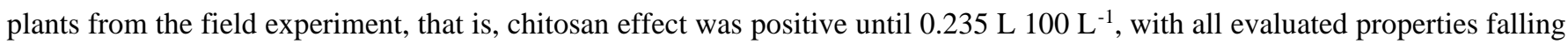

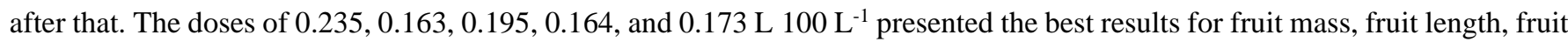
diameter, calyx length, and calyx diameter, respectively.

The application of chitosan provided a significant decrease in fruit mass for plants grown in the greenhouse (Figure 1). In this case, chitosan may have induced resistance mechanisms, thus providing a metabolic cost and reducing the energy available for growth (Gayler et al., 2004). According to Kuhn and Pascholati (2010), the plant uses photoassimilates for the production of constitutive defense in its tissues and the surplus is conducted to reserve tissues. When the plant needs energy to generate inducible defense mechanisms, part of its reserve is used. If the plant has low reserves, the photoassimilates are sent directly for the production of inducible defense.

It is important to emphasize that chitosan showed satisfactory results in the field experiment, especially at doses up to

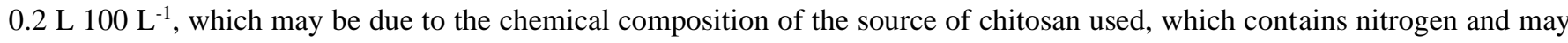
promote vegetative increment in some plants (Rabea et al., 2003). According to Mondal et al. (2012), foliar application of chitosan increases the main enzymatic activities of nitrogen metabolism (nitrate reductase, glutamine synthetase and protease) and improves the transport of nitrogen in the leaves, enabling a greater photosynthetic activity, which results in increased plant growth and development, as observed in our study. Furthermore, according to Bittelli et al. (2001), chitosan increases the availability and absorption of water and nutrients through the regulation of cellular osmotic pressure, producing better nourished 
plants and increased productivity, which was also observed in our study. Chitosan can also promote the reduction of harmful free radicals by increasing enzymatic and antioxidant activities of plants' secondary metabolism. This inhibits and/or reduces damage caused by free radicals resulting from abiotic processes, such as photosynthesis, solar radiation, and lack of water, and biotic processes such as pathogen and insect attacks (Guan et al., 2009).

In the greenhouse experiment, chitosan application did not show the same positive effects observed in the field experiment, probably because the plants were grown in pots, which limits their root development and results in damage to productivity. Plants grown in the greenhouse (Figure 1) presented lower values of fruit mass (21.8\%), FL (11.5\%), and FD $(11.1 \%)$ when compared to those grown in the field.

Abdel-Mawgoud et al. (2010) observed that the application of chitosan in strawberry leaves increases plant height, number of leaves, leaf biomass, and number of fruits per plant, with positive effects up to the dose of $2 \mathrm{~cm}^{3} \mathrm{~L}^{-1}$ and negative effects above that. El-Tanahy et al. (2012), in a study of foliar application of chitosan on cowpea beans, observed a positive effect on vegetative growth (plant height, fresh and dry mass of leaves) and pods length, mass and diameter, number of seeds, and seed yield. Ke et al. (2001) described that chitosan increased the development and growth of a rice crop due to the increase in nitrogen enzyme activity, which increases photosynthesis activity. The results of these studies are similar to those obtained in our study with physalis, indicating that the application of chitosan, although beneficial, must be controlled since it can produce negative effects when in excess.

Figure 1. Agronomic properties of physalis submitted to application of chitosan, both in a field experiment (FE) and in a greenhouse experiment (GE). A) Fruit mass-FM (g); B) Calyx diameter-CD (mm); C) Calyx length- CL (mm); D) Fruit lengthFL (mm); E) Fruit diameter-FD (mm). Horizontal and vertical bars indicate standard deviation $(F E: n=8$ and GE: $\mathrm{n}=5)$. ns and * refer to Tukey test $(\mathrm{P}<0.01)$ for the experimental conditions of each dose.

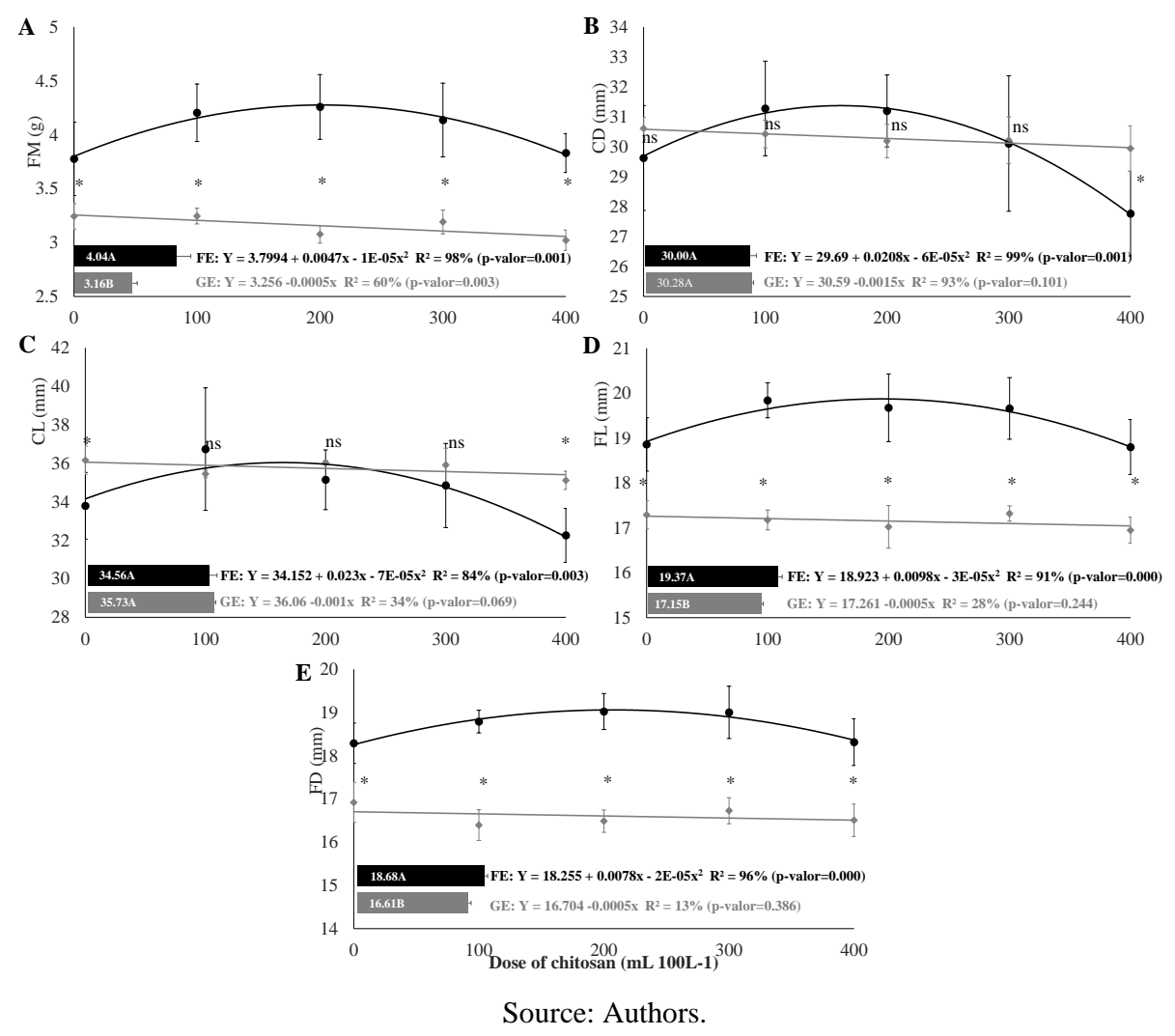


Unlike what was observed for the physical properties, SS and TA content (Figure 2 A and B) had a similar quadratic behavior in both the field and the greenhouse experiment. The maximum points for SS and TA content were 0.128 and $0.200 \mathrm{~L}$

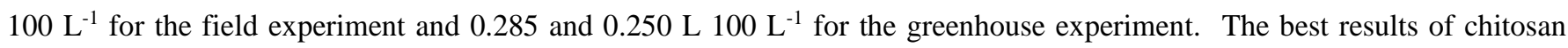

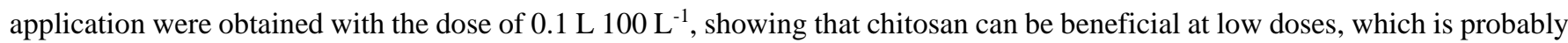
explained by its 6.89 to $8.75 \%$ nitrogen content (Rabea et al., 2003). According to Salim (1998), nitrogen favors an increase in fruits SS content.

With higher doses of chitosan, there is a greater stimulus of plant defense mechanisms and, according to Bittelli et al. (2001), chitosan can also reduce plant transpiration and water loss, promoting a decrease in osmotic potential of guard cells by reducing potassium concentration and stimulating stomatal closure. Thus, plants' tissues carry a greater quantity of water, diluting the concentration of organic compounds, which may explain the negative linear effect of the treatments with respect to fruit firmness (Figure 2C).

Figure 2. Chemical properties of fruits of physalis plants submitted to chitosan application, both in the field experiment (FE) and in the greenhouse experiment (GE). A) Soluble solids-SS ( ${ }^{\circ}$ Brix); B) Titratable acidity-TA (\% citric acid); C) Firmness-FF $(\mathrm{N})$. Horizontal and vertical bars indicate standard deviation (FE: $\mathrm{n}=8$ and GE: $\mathrm{n}=5)$. ns and * refer to Tukey test $(\mathrm{P}<0.01)$ for the experimental conditions of each dose.

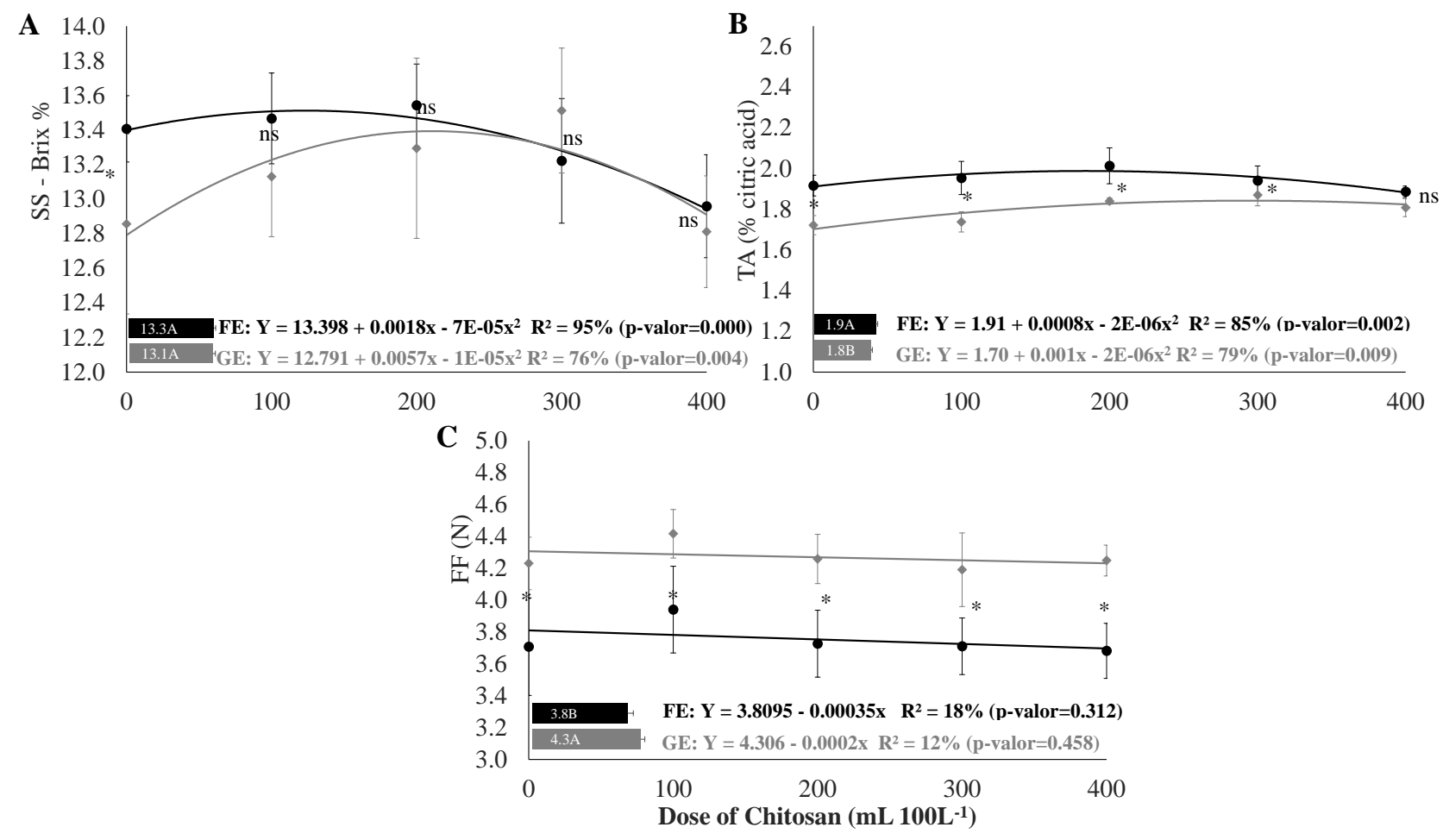

Source: Authors.

TA changed according to chitosan doses. However, it should be noted that lower values are desired for TA, since fruit taste is directly influenced by this property and fruits with high acidity do not have good commercial acceptance. Thus, the control and the highest doses of chitosan produced the best results (lower TA values).

Chitosan stimulates the production of secondary metabolites in plants, such as phenolic compounds, which protect them against attacks by phytopathogens (Bautista-Banos et al., 2006; Lei et al., 2011; Sathiyabama et al., 2016; Trouvelot et al., 2014). 
According to Chitarra and Chitarra (2005), these compounds alter fruit flavor because they increase astringency and titratable

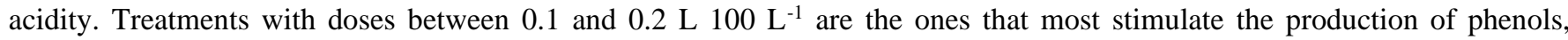
anthocyanins, tannins, and phytoalexins in physalis.

The high volume of rainfall during harvest (Figure 3) influenced the level of TA, since, according to Salim (1998), excess moisture decreases TA by increasing the amount of water in fruits and diluting acids.

According to Nascimento et al. (2003), fruits' sugar content and acidity are influenced by environmental factors, cultivation practices, sunlight quality, temperature, type and dose of fertilizer, which explains changes in SS and TA content, as well as in their ratio (SS/AT). Harvest and evaluation for this study occurred during winter (September and October). According to Maro et al. (2014), the environment has a strong influence on fruits' chemical properties, and a warmer climate generally favors the production of fruits with higher levels of SS.

The application of chitosan provided a decrease (although not significant) in fruit firmness (Figure 2C) for both experimental conditions. The application of chitosan generates a modified atmosphere that alters the circulating and internal air, reducing $\mathrm{O}_{2}$ levels, slowing water loss, and delaying the increase in polyphenoloxidase (PPO) activity, with consequent reduction of plant metabolism and senescence delay over time, which may be related to the reduction in firmness (Arnaud et al., 2016). Fruit firmness was $11.6 \%$ higher in the greenhouse experiment than in the field experiment (Figure 2C).

Figure 3. Meteorological data for the experimental evaluation period.

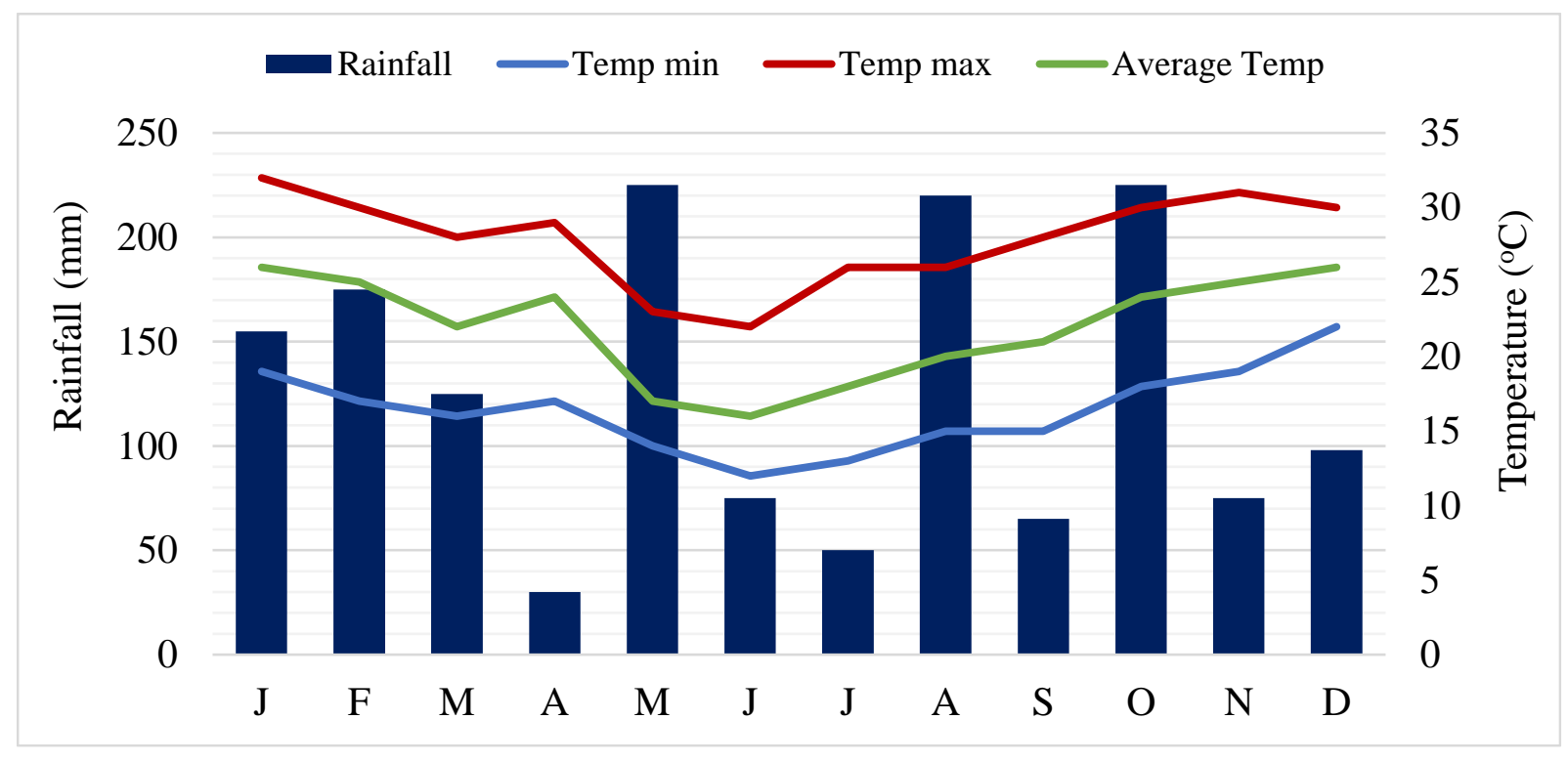

Source: Authors.

\subsection{Correlation analysis and PCA}

Significant positive correlations, although of low value, were found (Figure 4) between SS x TA $(r=0.36, P<0.01)$, SS x FM (r=0.26, P<0.05), SS x FL (r=0.34, P<0.01), SS x FD (r=0.30, P<0.05), TA x CD (r=0.26, P<0.05), Firmness x CL (r=0.37, $\mathrm{P}<0.01)$, Firmness x CD ( $\mathrm{r}=0.22, \mathrm{P}<0.05)$, and CD x FL ( $\mathrm{r}=0.31, \mathrm{P}<0.05)$. High significant and positive correlations (Figure 4) were found between fruit mass and TA ( $\mathrm{r}=0.71, \mathrm{P}<0.001)$, FL ( $\mathrm{r}=0.94, \mathrm{P}<0.001)$ and FD ( $\mathrm{r}=0.90, \mathrm{P}<0.001)$, as well as between TA and FL (r=0.73, P<0.001) and FD (r=0.74, P<0.001), CL x CD (r=0.82, P<0.001), and FL x FD (r=0.93, P<0.001). On the other hand, we found negative correlations $(\mathrm{P}<0.001)$ between fruit mass and firmness $(\mathrm{r}=-0.57)$ and Ratio $(\mathrm{r}=-0.61)$. Ratio is also negatively correlated with TA ( $\mathrm{r}=-0.82)$, FL(r=-0.61) and FD ( $\mathrm{r}=-0.68)$. The negative correlation between the Ratio and TA 
(Figure 4) is due to TA being the denominator for the Ratio's formula (SS/TA), and thus high titratable acidity values result in lower Ratio values.

Saavedra et al. (2019) found negative correlations between fruit mass and firmness, corroborating the results of our study, in which fruits with higher mass had lower firmness. Fruit firmness is an important factor because it is a determinant of shelf life adding greater commercial value.

The high correlations between fruit mass and fruit diameter and length are expected because larger fruits naturally have greater fruit mass.

High and significant correlations were also observed between TA and FL and FD, showing that there is a tendency for larger fruits to have higher TA values (Figure 4).

Figure 4. Pearson correlations (r) between the properties evaluated (values above the diagonal). To obtain the correlations, the properties evaluated in both conditions (field and greenhouse) were used, independent of chitosan doses $(\mathrm{n}=63)$. $* \mathrm{P}<0.05 ; * *$ $\mathrm{P}<0.01 ; * * * \mathrm{P}<0.001$. A histogram of properties distribution is shown on the diagonal. Correlograms are below the diagonal. Fruit Diameter (FD), Fruit Length (FL), Calyx Length (CL), Calyx Diameter (CD), Fruit Mass (FM), Soluble Solids Content (SS), Titratable Acidity (TA), SS/TA (Ratio), Fruit Firmness (FF).

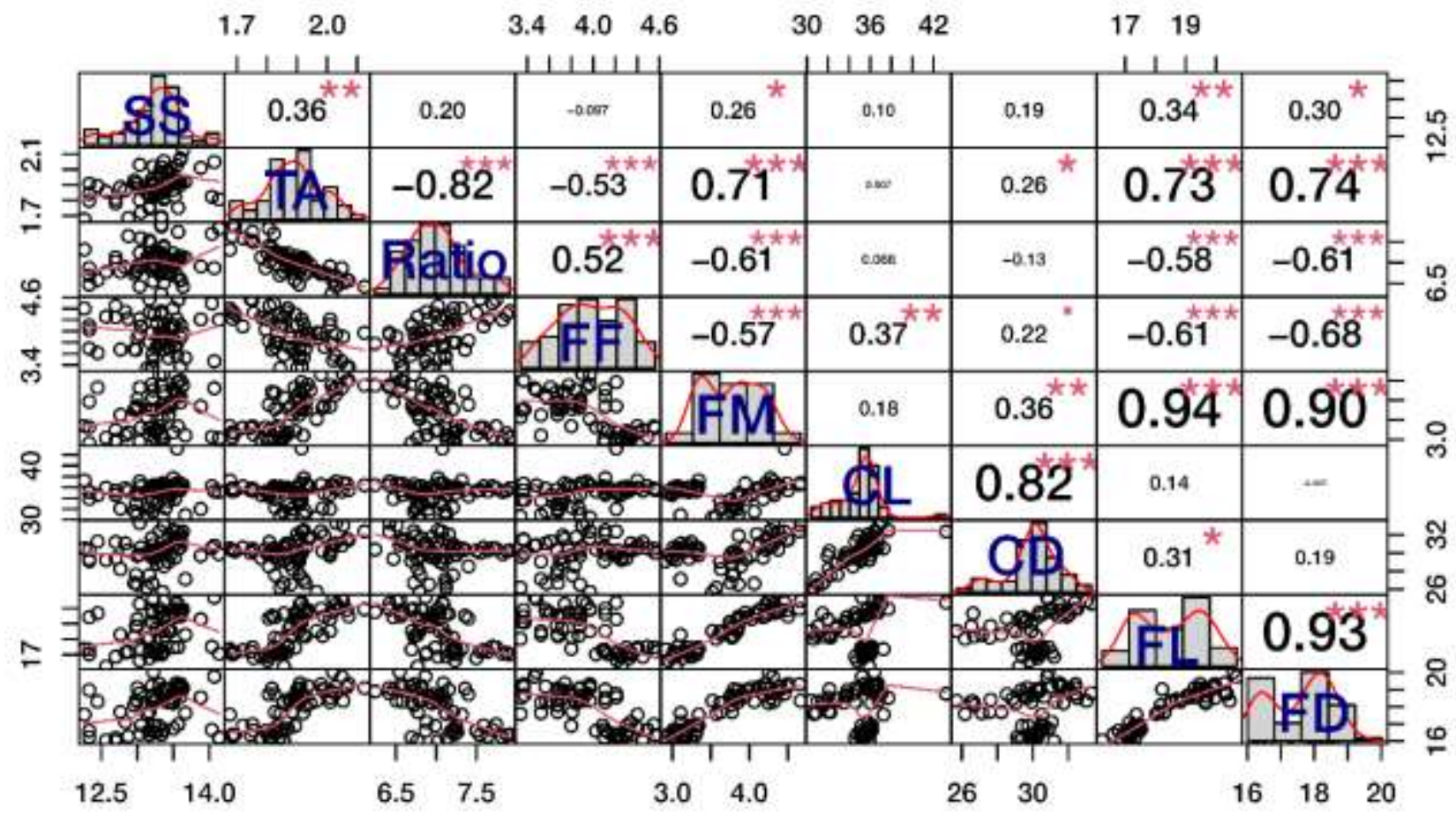

Source: Authors. 
For the field experiment, the first two axes of the PCA explained $89.72 \%$ of the total variation (Figure 5A). The first axis (PCA1) explains $71.63 \%$ of the variance and was negatively correlated only with Ratio (-0.58). The second axis (PCA2) explained approximately $18 \%$ of the variance and was correlated with Ratio, Firmness, CL, SS, CD, and FL. We observed a high

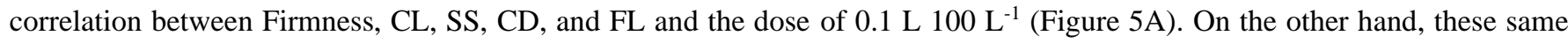
variables are inversely correlated with the dose of 0.4 L.100L ${ }^{-1}$. Mass, TA, and FD are highly associated with the doses of 0.2

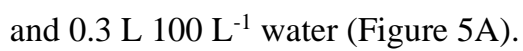

For the greenhouse experiment (Figure 5B), the first two axes explained $79.33 \%$ of the total variation. The first axis (PCA1) explained $49.58 \%$ of the variance and was negatively correlated only with TA (-0.64). The second axis (PCA2) explained $29.75 \%$ of the variance and was correlated with TA, SS, CL, FD, and FL (Figure 5B). In the greenhouse experiment, like in the

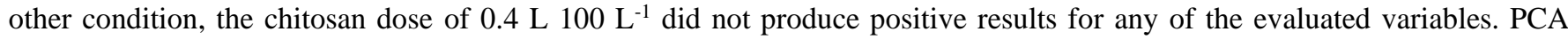

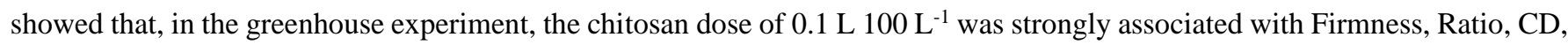

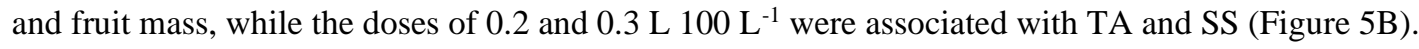

Figure 5. Multivariate principal component analysis (PCA). A) Biplot of the PCA for the field experiment (FE); B) Biplot of the PCA for the greenhouse experiment (GE). Fruit Diameter (FD), Fruit Length (FL), Calyx Length (CL), Calyx Diameter (CD), Fruit Mass (FM), Soluble Solids Content (SS), Titratable Acidity (TA), SS/TA (Ratio), Fruit Firmness (FF).

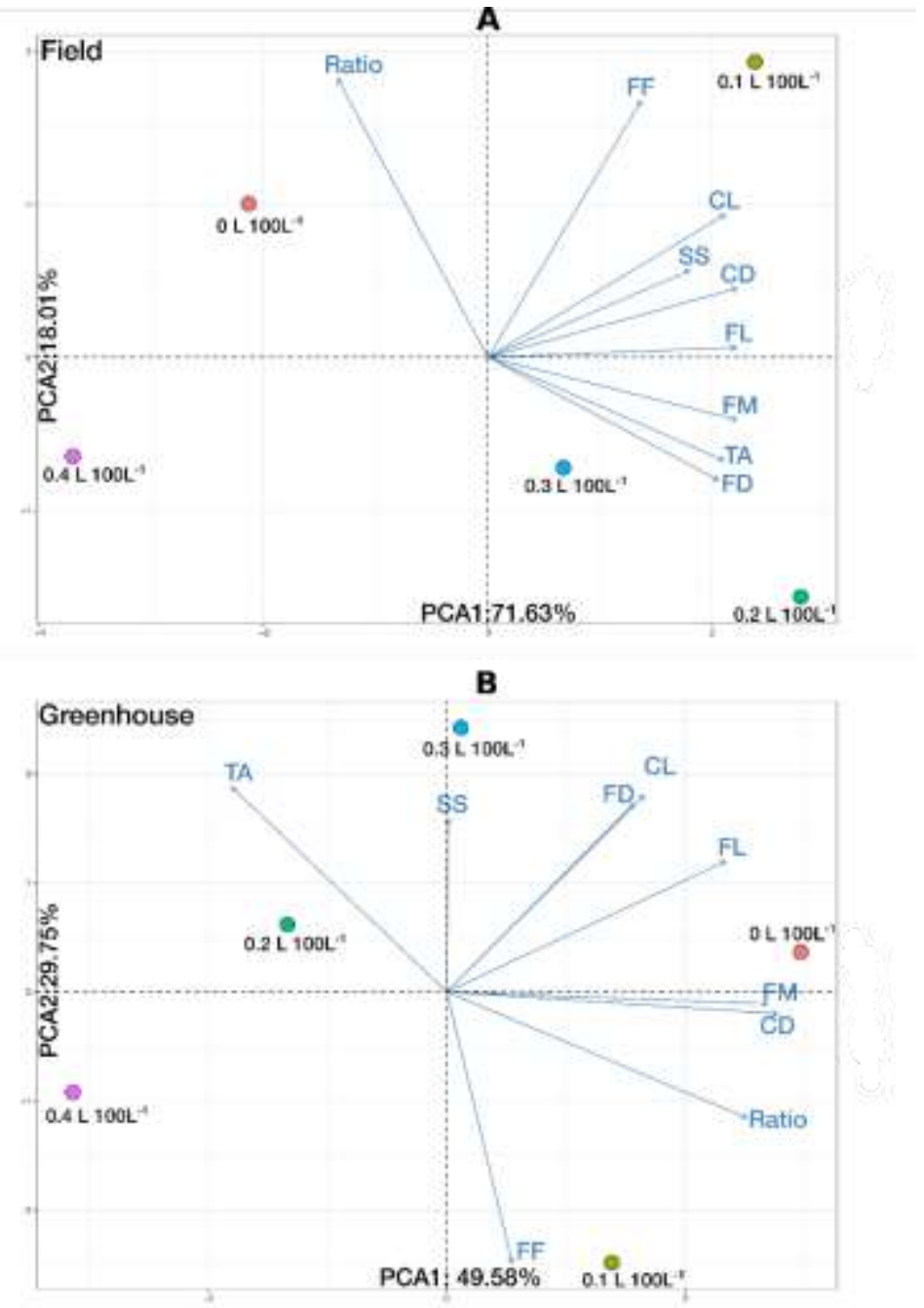

Source: Authors. 


\section{Conclusion}

Foliar application of chitosan has a positive effect on physicochemical properties of field-grown physalis fruits. This

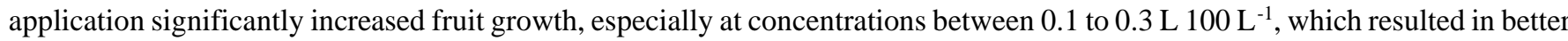
physical characteristics. Chitosan negatively affects chemical properties. When in high doses, it increases TA and decreases SS content. This effect, however, does not result in great damage because the fruits still maintain commercial quality. Foliar

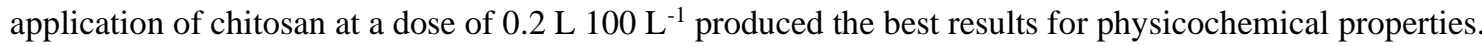

In the future, it would be interesting to evaluate the application of chitosan at different stages of development, in addition to its evaluation as an inducer of disease resistance.

\section{References}

Abdel-Mawgoud, A. M. R., Tantawy, A. S., El-Nemr, M. A., Sassine, Y. N. (2010). Growth and yield responses of strawberry plants to chitosan application. European Journal of Scientific Research. 39 (1), 170-177.

Amerany, F. E., Rhazi, M., Wahbi, S., Taourirte, M., Meddich, A. (2020). The effect of chitosan, arbuscular mycorrhizal fungi, and compost applied individually or in combination on growth, nutrient uptake, and stem anatomy of tomato. Scientia Horticulturae, 261, doi.org/10.1016/j.scienta.2019.109015.

Arnaud, T. M. S., Stamford, T. C. M., Stamford, T. L. M., Stamford, N. P. (2016). Produção, propriedades e aplicações da quitosana na agricultura e em alimentos: Biotecnologia Aplicada à Agro\&Indústria. 1ed. (Livro eletrônico), 503-528.

Bautista-Banos, S., Hernández-Lauzardo, A. N., Valle, M. G., López, M., Barka, E. M., Molina, E. B., Wilson, C. L. (2006). Chitosan as a potential natural compound to control pre and postharvest diseases of horticultural commodities. Crop Prot. 25, 108-118. doi: 10.1016/j.cropro.2005.03.010.

Berger, L., Stamford; T., Stamford, N. (2011). Perspectivas para o uso da quitosana na agricultura. Revista Iberoamericana de Polímeros. 12 (4), $195-215$.

Bittelli, M., Flury, M., Campbell, G., Nichols, E. (2001). Reduction of transpiration through foliar application of chitosan. Agricultural and Forest Meteorology. $107,167-175$.

Caviglione, J. K., Kiikl, L. R., Aramori, P. H., Oliveira, D. (2000). Cartas climáticas do Paraná. Londrina - PR: 1 CD-ROM. IAPAR, 2000.

Chitarra, M. I. F., Chitarra, A.B. (2005). Pós-colheita de frutas e hortaliça: Fisiologia e Manuseio. 2. ed. Lavras: UFLA, p.783.

Core Team, R. (2020). R: A language and environment for statistical computing. $R$ Foundation for Statistical Computing, Vienna, Austria. https://www.Rproject.org/.

EMBRAPA. Empresa Brasileira de Pesquisa Agropecuária. (2018). Sistema Brasileiro de Classificação de solos. 5 ed., p.356. Embrapa solos Brasília - DF.

Fai, A. E. C., Stamford, T C. M., Stamford-Arnaud, T. M., Santa-Cruz, P. A., Silva, M .C. F., Campos-Takaki, G. M., Stamford, T. L. M. (2011). Physico chemical characteristics and functional properties of chitin and chitosan produced by mucor circinelloides using yam bean as substrate. Molecules. 16, 71437154.

Ferreira, D. F. (2008). Um programa para análises e ensino de estatística. Revista Científica Symposium, Lavras. 6 (2), 36-41. doi: 10.3390/molecules16087143.

Fischer, G., Almanza-Merchán, P. J., Miranda, D. (2014). Importancia y cultivo de la uchuva (Physalis peruviana L.). Revista Brasileira de Fruticultura. 36 (1), 001-015. doi: https://doi.org/10.1590/0100-2945-441/13.

Gayler, S., Leser, C., Priesack, E., Treutter, D. (2004). Modelling the effect of environmental factors on the "trade off” between growth and defensive compounds in young Apple trees. Springer Berlin / Heidelberg. Trees-Struct. Funct. 18 (3), 363-371.

Guan, Y., Hu, J., Wang, X., Shao, C. (2009). Seed priming with chitosan improves maize germination and seedling growth in relation to physiological changes under low temperature stress. Journal of Zhejiang University Science A. 10(6), 427-433. doi: 10.1631/jzus.B0820373.

Hammer, O., Harper, D. A. T., Ryan, P. D. (2001). PAST: Paleontological statistics software package for education and data analysis. Palaeontologia Electronica. 4 (1), 1-9.

Instituto Adolfo Lutz. (2008). Normas Analíticas do Instituto Adolfo Lutz. Métodosquímicos e físicos para a análise de alimentos. 3 ed. p.533, São Paulo.

Ke, L., Yang, L. X., Lisha, P. (2001). Effects of carboxymethyl chitosan on key enzymes activities of nitrogen metabolism and grain protein contents in rice. Journal Hunan Agricultural University. 27 (6), 421-424.

Kuhn, O. J., Pascholati, S. F. (2010). Custo adaptativo da indução de resistência em feijoeiro mediada pela rizobactériaBacillus cereusou acibenzolar-S-metil: atividade de enzimas, síntese de fenóis e lignina e biomassa. Summa Phytopathologica. 36 (2), 107-114.

Kumar, M. N. R. (2000). A review of chitin and chitosan applications. React. Funct. Polym.46 (1), 1-27. doi: 10.1016/S1381-5148(00)00038-9.

Kurtz, M. C., Cruz, A. H., Retamoso, V., Drehmer, P. B.; Silveira, V., Kirsten, V.R. (2010). Quitosana na redução de colesterol e perda de peso: uma revisão da literatura. Jornada Interdisciplinar em Saúde. Santa Maria, RS: UNIFRA. doi: 10.21877/2448-3877.201700553. 
Research, Society and Development, v. 11, n. 2, e24111225825, 2022

(CC BY 4.0) | ISSN 2525-3409 | DOI: http://dx.doi.org/10.33448/rsd-v11i2.25825

Lei, C., Ma, D., Pu, G., Qiu, X., Du, Z., Wang, H., Li, G., Ye, H., Liu, B. (2011). Foliar application of chitosan activates artemisinin bio-synthesis in Artemisia аппиа L. Industrial Crop sand Products. 33 (1), 176-182. doi:10.1016/j.indcrop.2010.10.001.

Machado, T. F., Monteiro, E. R., Tiecher, A. (2019). Estabilidade química, físico-química e antioxidante de polpa de Physalis pasteurizada e não pasteurizada sob congelamento. Brasilian Journal of Food Technology. 22, e2017149. doi: 10.1590/1981-6723.14917.

Maro, L.A.C., Pio, R., Guedes, M.N.S., Abreu, C.M.P., Moura, P.H.A. (2014). Environmental and genetic variation in the post-harvest quality of raspberries in subtropical areas in Brazil. Acta Scientiarum. Agronomy. 36 (3), 323-328. doi: 10.4025/actasciagron.v36i3.18050.

Marchioretto, L. D. R., Rossi, A. D., Conte, E. D. (2020). Chemical root pruning improves quality and nutrient uptake of Cape Gooseberry (Physalis peruviana) seedlings. Scientia Horticulturae. 261. doi: 10.1016/j.scienta.2019.108948.

Mier-Giraldo, H., Diaz-Barrera, L. E., Delgado-Murcia, L. G., Valero-Valdivieso, M. F., Cáez-Ramírez, G. (2017). Cytotoxic and immunomodulatory potential activity of Physalis peruviana fruit extracts on cervical cancer (HeLa) and fibroblast (L929) cells. Journal of Evidence-based Complementary \& Alternative Medicine. 22 (4), 777-787. doi: 10.1177/2156587217718751.

Mondal, M. M. A., Malek, M. A., Puteh, A. B., Ismail, M.R., Ashrafuzzaman, M., Naher, L. (2012). Effectof foliar application of chitosan on grow thand yield in okra. Australian Journal of Crop Science. 6 (5), 918-921.

Muniz, J., Kretzschmar, A. A., Rufato, L., Pelizza, T. R., Marchi, T., Duarte, A. E., Lima, A.P.F., Garanhani, F. (2011). Sistemas de condução para o cultivo de Physalis no planalto catarinense. Revista Brasileira de Fruticultura. 33 (3), 830-838. doi: 10.1590/S0100-29452011005000083.

Muniz, J., Kretzschmar, A. A., Rufato, L., Pelizza, T. R., Rufato, A. R.; Marcelo, T. A. (2014). General aspects of Physalis culltivation. Ciência Rural. 44 (6), 964-970. doi: 10.1590/S0103-84782014005000006

Nascimento, W. M. O., Tomé, A. T., Oliveira, M. S. P., Müller, C. H., Carvalho, J.E.U. (2003). Seleção de progênies de maracujazeiro-amarelo (Passiflora edulisf. flavicarpa) quanto à qualidade de frutos. Revista Brasileira de Fruticultura. 25, 186-188.

Puente, L., Pinto, M. C., Castro, E., Cortés, M. (2011). Physalis peruviana L, the multiple properties of a highly functional fruit: A review. Food Research International. 44, 1733-1740.

Rabea, E. I., Badawy, M. E. T., Stevens, C., Smagghe, G., Steurbaut, W. (2003). Chitosan as antimicrobial agent: applications and mode of action. Biomacromolecules. 4 (3), 1457-1465. doi: 10.1021/bm034130m.

Rodrigues, F. A., Penoni, E. S., Soares, J. D. R., Silva, R. A. L., Pasqual, M. (2014). Chemical, physical and physical-chemical characterization of physalis cultivated in greenhouse. Ciência Rural. 44 (8), 1411-1414. doi: 10.1590/0103-8478cr20130743.

Saavedra, J. C. M., Zaragoza, F. A. R., Toledo, D. C., Hernández, C.V.S., Vargas-Ponce, O. (2019). Agromorphological characterization of wild and weedy populations of Physalis angulata in Mexico. Scientia Horticulturae. 246, 86-94. doi: 10.1016/j.scienta.2018.10.055.

Salim, S. (1998). Tratado de fruticultura. Piracicaba: FEALQ, p.760.

Sathiyabama, M., Akila, G. (2021). Water soluble Chitosan extraction from mycelium of Alternaria solani and its field evaluation on Tomato plants. Carbohydrate Polymer Technologies and Applications. 2, 100-101. doi: 10.1016/j.carpta.2021.100101.

Sathiyabama, M., Bernstein, N., Anusuya, S. (2016). Chitosan elicitation for increased curcumin production and stimulation of defense response in turmeric (Curcuma longa L.). Industrial Crops and Products. 89, 87-94. doi: 10.1016/j.indcrop.2016.05.007.

Synowiecki, J., Khateeb, N. A. A. (2003). Production, properties, and some new applications of chitin and its derivatives. Critical Reviews in Food Science and Nutrition. 43 (2), 145-171. doi: 10.1080/10408690390826473.

Trani, P. E., Kariya, E. A., Hanai, S. M., Anbo, R. H., Basseto Junior, O. B., Purqueiro, L. F. V., Trani, L. (2015). Calagem e adubação do tomate de mesa. IAC - Instituto Agronômico de Campinas, p.35. online. (Série Tecnologia Apta. Boletim Técnico IAC, 215).

Trouvelot, S., Heloir, M. C., Poinssot, B., Gauthier, A., Paris, F., Guillier, C., Combier, M., Trda, L., Daire, X., Adrian, M. (2014). Carbohydrates in plant immunity and plant protection: roles and potential application as foliar sprays. Front. in Plant Sci. 5, 592. doi: 10.3389/fpls.2014.00592.

Valdivia-Mares, L. E., Zaragoza, F. A. R., González, J. J. S., Vargas-Ponce, O. (2016). Phenology, agronomic and nutritional potential of three wild husk frit species (Physalis, Solanaceae) from Mexico. Scientia Horticulturae, 200, 83-94. doi: 10.1016/j.scienta.2016.01.005. 